\title{
A new species of Begonia L. (Begoniaceae) from Dampa Tiger Reserve, Mizoram, India
}

\author{
Odyuo N., B.K. Sinha ${ }^{1}$, Murugesan, $\mathbf{M}^{2}$ and A. Uddin \\ Botanical Survey of India, Eastern Regional Centre, Shillong - 793003, Meghalaya, India. \\ ${ }^{1}$ Botanical Survey of India, Head quarters, Kolkata - 700064, West Bengal, India. \\ ${ }^{2}$ Corresponding author, e-mail: taxonmurugesh@gmail.com
}

[Received 25.04.2018; Revised 22.06.2018; Accepted 23.06.2018; Published 30.06.2018]

\begin{abstract}
Begonia dampae sp. nov. a new species belongs to the family Begoniaceae, collected from Dampa Tiger Reserve, Mizoram, India is described and illustrated here along with a note on Group-II of the Section Diploclinium to which the species belongs. The new species is similar to Begonia ovatifolia A.DC. but can be readily distinguished by its caulescent habit, $0.8-2.2 \mathrm{~cm}$ long, glabrous, hyaline, green, petioles; ovate-cordate, asymmetric, $3.5-3.8 \times 2-2.5 \mathrm{~cm}$, crenate-doubly crenate leaves; ovate-lanceolate, crenate, $3-5 \times 1-2 \mathrm{~mm}$ stipules; $3-8$ flowered raceme inflorescence with $0.6-1.2 \mathrm{~cm}$ long peduncle; ovate bracts; ovate-cordate sepals, ovate-lanceolate petals in male flowers; $5-6$ tepals with ovate-cordate outer tepals, narrowly lanceolate inner tepals in female flowers; 14 stamens and all unequal wings in fruits.
\end{abstract}

Key words: Begonia dampae sp. nov., Sect. Diploclinium, Dampa Tiger Reserve, Mizoram, North-east India.

\section{INTRODUCTION}

The family Begoniaceae contains 2 genera; the monotypic Hillabrandia Oliver, which is endemic to the Hawaiian Islands and the species rich Begonia L. Begonia is the sixth largest angiosperm genus in the world. According to Smith et al. (1986), Doorenboss et al. (1998), Frodin (2004), Sands, (2009) and Stults \& Axsmith (2011) the genus Begonia is estimated to have 1600 species and are classified under 66 sections. The genus consists of herbs, shrubs and lianas, and distributed throughout tropical and subtropical regions of the world, except northern Australia. Doorenboss et al. (1998) in their infra-generic revision of Begonia recognized 63 sections (29 from America, 18 from Asia and 16 from Africa) with altogether 1376 species. Subsequently, 3 more sections were added to the genus (Tebbitt 2005). Clarke (1879 \& 1881) reported ca. 65 species of Begonia in The Flora of British India. After this, only sporadic works has been done on the family (Ahmedullah \& Nayar 1987; Panda \& Das 1997; Walter \& Gillett 1998; Rao et al. 2003; Ambrish \& Uddin 2006; Uddin \& Phukan 2007.). During revision of the family under Flora of India Project, 7 sections and 56 species were encountered from the present Indian Territory (Uddin 2007; Uddin \& Phukan 2007). A total of 18 species are included under various threat categories (Ahmedullah \& Nayar, 1987; Nayar 1996; Nayar, \& Sastry, 1987-1990). Seven species of Indian Begonia are represented only by the type collections housed at K and CAL (Uddin 2007). The Southeast Asian species of Begonia remain the most poorly known, with many novelties still 
being discovered even today (Thomas et al. 2011; Girmansyah 2012; Phutthai et al. 2012; Sang et al. 2013).

An interesting species of Begonia was collected during the floristic exploration of Dampa Tiger Reserve, Mizoram, North-east India in May 2005. It was introduced in the garden of Botanical Survey of India, Eastern Regional Centre, Shillong where it survived only for two years. Specimens were prepared and photographs of the plants and plant parts were taken from the introduced plants and were left unattended with the senior author. While preparing the checklist for the Flora of Nagaland with particular reference to Begoniaceae, the senior author noticed the specimens. Ana, after critical examination with relevant literatures, consultation of major herbaria for the region viz. K, CAL, ASSAM, BSD, BSI, BLAT, MH, ARUN etc. and authentic types, it was concluded that the species belongs to Sect. Diploclinium which is revealed by the 3 celled ovary with bifid placentae and the filaments of the stamens produced beyond the anther lobes and the specimens could not be delimited under any known species from India and adjoining countries and eventually turned out to be a new species. A detailed morphological description of the species and colour plates coupled with distinctive features with the allied species and a critical note on the Group-II of Sect. Diplopclinium of Begonia are provided. The plant is now named as Begonia dampae after the name of the Dampae Tiger Reserve, Mizoram.

Begonia dampae is classified under Group-II of section Diploclinium. This is one of the largest sections of Begonia reported exclusively from Asia. This section includes ca. 142 species classified into 3 Groups (Doorenbos el al. 1998). From India 14 species are recorded so far under this section, distributed throughout the North-Eastern States, the Himalayas and the Western Ghats. The 3 locular ovary with bifid placenta and 3 winged fruits distinguish the section from the allied Asiatic ones viz. sect. Platycentrum, sect. Reichenehmia and sect. Parvibegonia. This Group-II is often characterized by tuberous stem, united filaments and more or less free styles. This group has a total of 46 species out of which 9 are recorded from India.

\section{Taxonomic treatment:}

Begonia dampae Odyuo, Sinha, Murugesan \& Uddin, sp. nov. [PLATE - I]

Type: INDIA, Dampa Tiger Reserve, Mizoram (Lat. 23³6'58" N, Long. 92017’24" E), 450 m elevation, 30.05.2005, Odyuo 109868 (Holotype: ASSAM! Isotypes: CAL).

Begonia dampae sp. nov. is closely allied to Begonia ovatifolia A.DC. but can be readily distinguished by its caulescent habit, and $0.8-2.2 \mathrm{~cm}$ long, glabrous, hyaline, green petioles; ovate - cordate, asymmetric, $3.5-3.8 \times 2-2.5 \mathrm{~cm}$, crenate-doubly crenate lamina; ovate-lanceolate, crenate, $3-5 \times 1-2 \mathrm{~mm}$ stipules; $3-8$ flowered raceme with $0.6-1.2$ $\mathrm{cm}$ long peduncle; ovate bracts; ovate-cordate sepals, ovate-lanceolate petals in male flowers; $5-6$ tepals with ovate-cordate outer tepals, narrowly lanceolate inner tepals in female flowers; 14 stamens and all unequal wings in fruits. (Table 1)

Erect, tuberous, caulescent, monoecious herb, $4.7-6.9 \mathrm{~cm}$ high. Roots fibrous, tubers ovate or ovate-oblong, rarely irregular shaped, $2.5-3.2 \mathrm{~cm}$ across. Stem unbranched, glabrous. Leaves $3-4$, alternate, cauline; petioles of $0.8-2.2 \mathrm{~cm}$ long, $1-2 \mathrm{~mm}$ in diameter, glabrous, hyaline; lamina $2.8-4.5 \times 1.8-2.5 \mathrm{~cm}$, ovate-cordate, asymmetric at base, crenate doubly crenate or dentate, acute-shortly acuminate, adaxially pilose, pubescent on the nerves beneath; venation palmate, mid-rib prominent, lateral nerves $7-8$ paired; stipules $3-5 \times 1$ $-2 \mathrm{~mm}$, ovate-lanceolate, serrate, acuminate. Racemes of $3-8$ flowers; peduncle $0.6-1.2$ cm long, glabrous; bracts $2-3 \times 1.0-2.5 \mathrm{~mm}$, ovate, acuminate, persistent, glabrous. Male 


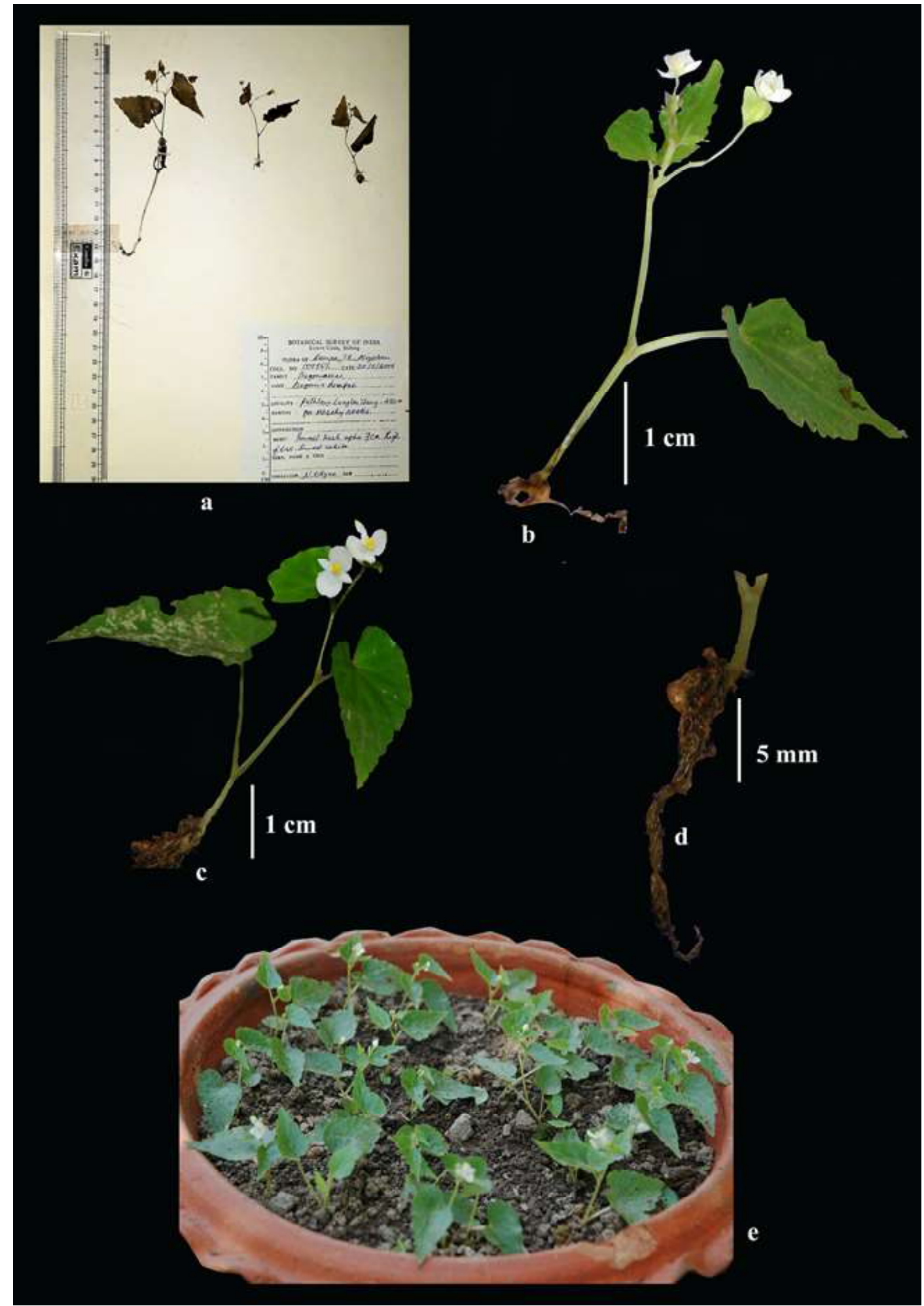

PLATE - I. Begonia dampae: a. Herbarium specimen (Type); b. Plant with female flowers; c. Plant with male flowers; d. root tuber; e. live plants in pot 
flowers: pedicel $0.7-1.0 \mathrm{~cm}$; sepals 2 , ovate - cordate, $5-6 \times 4-5 \mathrm{~mm}$, entire, acute obtuse, glabrous, white; petals 2, ovate - lanceolate, $5-6 \times 1-2 \mathrm{~mm}$, entire, acute, glabrous, white; stamens $10-14$, slightly monadelphous; filaments $1-1.5 \mathrm{~mm}$ long; anthers $2.0-2.5$ $\mathrm{mm}$ long, bithecous, yellow. Female flowers: pedicels $6-7 \mathrm{~mm}$ long; tepals $5-6$; outer tepals ovate-cordate, $4-5 \times 3-4 \mathrm{~mm}$, inner ones gradually smaller; innermost tepal $5-6$ $\times 3-4 \mathrm{~mm}$, narrow - lanceolate, entire, acute, glabrous, white; ovary 3 locular, glabrous; placentation axile; placentae bifid with numerous ovules in each lamellae; stigmas 3, persistent; styles lunate, shortly fused at the base, $2-3 \mathrm{~mm}$ long, $1.5-2.0 \mathrm{~mm}$ wide at apex. Capsules 3 -winged, 3 celled; wings unequal, produced $2-3 \mathrm{~mm}$ below the ovary cells; two shorter wings 3-4 mm long with blunt ends; longer wing $7-7.5 \mathrm{~mm}$ long, tapering up or ascending from the plane, acute, glabrous, with ventral suture between the adjacent wings; dehiscing by the medial lines in each face. Seeds ellipsoid.

Etymology: The species is named after the type locality Dampa Tiger Reserve, Mizoram, India, from where the new taxon is described.

Flowering \& Fruiting: July - September.

Distribution: India, Mizoram, Dampa Tiger Reserve.

Ecology \& Habitat: The plant grows under dense sub-tropical forests, on sandy soils or rocks in moist shady places in association with Polytrichum spp., Funeria sp., Selaginella spp., Colocasia sp., Impatiens spp. etc.

Affinity: The new species is quite close to Begonia ovatifolia A.DC. but can be easily distinguished as shown in Table 1.

Table 1. Distinguishing features of Begonia dampae sp. nov. with Begonia ovatifolia.

\begin{tabular}{|c|c|c|}
\hline Character & Begonia dampae & Begonia ovatifolia \\
\hline 1. Habit & $\begin{array}{l}\text { Caulescent herb, } 4.7-6.9 \mathrm{~cm} \\
\text { high }\end{array}$ & $\begin{array}{l}\text { Acaulescent or subcaulescent } \\
\text { herb, } 10-20 \mathrm{~cm} \text { high }\end{array}$ \\
\hline 2. Petioles & $\begin{array}{l}0.8-2.2 \mathrm{~cm} \text { long, glabrous, } \\
\text { hyaline, green }\end{array}$ & $\begin{array}{l}\text { In basal leaves } 2.5-10 \mathrm{~cm} \\
\text { long; and in cauline leaf } 1.8- \\
4.2 \mathrm{~cm} \text { long, pubescent }\end{array}$ \\
\hline 3. Stipules & $\begin{array}{l}\text { Ovate-lanceolate, crenate, } 3- \\
5 \times 1-2 \mathrm{~mm}\end{array}$ & $\begin{array}{l}\text { Lanceolate, serrate, } 1.5 . \mathrm{x} 1 \\
\mathrm{~mm}\end{array}$ \\
\hline 4. Lamina & $\begin{array}{l}\text { Ovate - cordate, asymmetric, } \\
3.5-3.8 \times 2-2.5 \mathrm{~cm}, \\
\text { crenate-doubly crenate }\end{array}$ & $\begin{array}{l}\text { Broadly ovate-cordate, } \\
\text { symmetric, } 4.2-6.5 \times 3.5- \\
6.2 \mathrm{~cm} \text {, serrate-denticulate }\end{array}$ \\
\hline 5. Inflorescence & $\begin{array}{l}\text { Raceme, } 3-8 \text { flowered; } \\
\text { peduncle } 0.6-1.2 \mathrm{~cm} \text { long. }\end{array}$ & $\begin{array}{l}\text { Biparous cymes, } 4-8 \text {-flowered; } \\
\text { peduncle } 3.6-9.5 \mathrm{~cm} \text { long. }\end{array}$ \\
\hline 6. Bracts & Ovate & Oblong-lanceolate \\
\hline 7. Sepals in male flowers & Ovate-cordate & Obovate \\
\hline 8. Petals in male flowers & Ovate-lanceolate & Obovate \\
\hline 9. Tepals in female flowers & $\begin{array}{l}5-6 \text {; outer tepals ovate- } \\
\text { cordate; inner narrowly } \\
\text { lanceolate }\end{array}$ & $\begin{array}{l}3 \text {; outer tepals obovate; } \\
\text { obovate-lanceolate }\end{array}$ \\
\hline 10. Number of stamens & \pm 14 & \pm 20 \\
\hline 11. Wings of capsule & $\begin{array}{l}\text { All unequal, produced below } \\
\text { the ovary cells }\end{array}$ & $\begin{array}{l}\text { Two laterals are equal, one } \\
\text { distal larger; not produced } \\
\text { below the ovary cells }\end{array}$ \\
\hline
\end{tabular}


Conservation status: The new species is currently known only from the type locality. During the exploration trip we could collect only 14 individuals within the Dampa Tiger Reserve, Mizoram by covering as area of $1 \mathrm{~km}^{2}$. This data has been evaluated according to the IUCN Red List Categories and Criteria version 3.1 (IUCN 2012) and this species has been provisionally assessed here as Data Deficient (DD). However, it is also suggested that further detailed explorations in similar habitats of entire Dampa Tiger Reserve, Mizoram, are required to know its population size, area of occupancy and extent of occurrence and threats, if any, to assess the exact threat category of the species. Habitat destruction caused by wild fires, fire wood collection and cattle grazing are the major threats that was determined during the study period.

\section{Acknowledgements}

The authors are grateful to Dr. M. Sanjappa, the then Director, Botanical Survey of India, Kolkata and Dr. T.M. Hynniewta, then Joint Director, BSI, EC, Shillong for providing facilities. They are also grateful to Dr. Paramjit Singh Director BSI and Dr. Ashiho A. Mao, Scientist-F and Head of Office, BSI, ERC, Shillong for their kind support. Thanks are also due Forests Authorities, Government of Mizoram for various helps during the exploration tour to Dampa Tiger Reserve. They are also thankful to Dr. Martin Sands of K for his expert comments and to Dr. Srivastava - the then IBLO.

\section{LITERATURES CITED}

Ahmedullah, M. \& Nayar, M.P. 1987. Endemic Plants of the Indian Region. Vol. 1. Peninsular India. Botanical Survey of India, Calcutta.

Ambrish, K. \& Uddin, A. 2006. Rediscovery of an endemic and endangered plant Begonia tessaricarpa C.B. Clarke) from Arunachal Pradesh, India, after a century. Curr. Sci. 91(8): $997-998$.

Clarke, C.B. 1879. In: Hooker, J.D. (ed.), The Flora of British India. Vol. II. L. Reeve \& Co., London. Pp. $635-656$.

Clarke, C.B. 1881. On the Indian Begonias. J. Linn. Soc., Bot. 18: 114 - 122. pt. I-III

Doorenbos, J.; Sosef, M.S.M. \& de Wilde, J.J.F.E.. 1998. The Sections of Begonia, including descriptions, key and species lists (Studies in Begoniaceae VI). Wageningen Agricultural University Papers. Wageningen.

Frodin, D.G. 2004. History and concepts of big plant genera. Taxon 53: 753 - 776.

Girmansyah, D. 2012. Begonia ranaiensis (Begoniaceae), a new species from Mt Ranai, Natuna Island, Indonesia. Kew Bull. 68: 1 - 4.

IUCN, 2012.. IUCN Red List Categories and Criteria. Version 3.1. IUCN, Species Survival Commission, Gland

Nayar, M.P. \& Sastry, A.R.K. 1987-1990. Red Data Book of Indian plants. Vols. 1-3. Botanical Survey of India, Howrah.

Nayar, M.P. 1996. Hotspots of Endemic plants of India, Nepal and Bhutan. Tropical Botanic Garden and Research Institute, Thiruvananthapuram. New Delhi.

Panda, S. \& Das, A.P. 1997: Begonias of Eastern Himalayas: an appraisal. J. Natl. Bot. Soc. 51: $79-82$.

Phutthai, T.; Hughes, M. \& Sridith, K. 2012. A new species of Begonia (Begoniaceae) from Peninsular Thailand. Edinb. J. Bot. 69(2): 287 - 292. 
104 Begonia dampae sp. nov. from Mizoram

Rao, C.K.; Geetha, B.L. \& Geetha S. 2003. Red List of Threatened Vascular Plant Species in India. ENVIS, Botanical Survey of India, Howrah.

Sands, M.J. 2009. The Begonias of New Guinea - An overview. Blumea 54: 272 - 277.

Sang, J.; Kiew, R. \& Geri, C. 2013. Revision of Begonia (Begoniaceae) from the Melinau Limestone in Gunung Mulu National Park and Gunung Buda National Park, Sarawak, Borneo, including thirteen new species. Phytotaxa 99(1): $1-34$.

Smith, L.B.; Wasshausen, D.C.; Golding, J. \& Karegeannes, C.E. 1986. Begoniaceae. Part-I: Illustrated Key, Part-II: Annotated Species List. Smithsonian Institution Press, Washington.

Stults, D.Z. \& Axsmith, B.J. 2011. First Macrofossil Record of Begonia (Begoniaceae). Amer. J. Bot. 98(1): $150-153$.

Thomas, D.C.; Ardi, W.H. \& Hughes, M. 2011. Nine new species of Begonia (Begoniaceae) from South and West Sulawesi, Indonesia. Edinb. J. Bot. 68(2): 225 -255. doi:10.1017/ S0960428611000072.

Tebbitt, M.C. 2005. A New Species of Fleshy Fruited Begonia (Begoniaceae) from Sumatra. Blumea 50: 153 - 156.

Uddin, A. 2007 Distribution and Status of Indian Begonia L. Species J. Econ. Taxon. Bot. 31(3): $591-597$.

Uddin A. \& Phukan, S. 2007. Notes on Begonia aborensis Dunn.-a New Record from Assam, India. J. Econ. Taxon. Bot. 31(1): 160.

Walter, K.S. \& Gillett H.J. (eds.) 1998. 1997 IUCN Red List of Threatened Plants. Compiled by the World Conservation Monitoring Centre. IUCN, Gland. pp. $72-74$. 